УДК 004.942.519.87(045)

\author{
О. Г. Аодонов, А. І. Кузьмичов, В. В. Бочаров \\ Інститут проблем реєстрації інформації НАН України \\ вул. М. Шпака, 2, 03113 Київ, Україна \\ e-mail:dodonov@ipri.kiev.ua, akuzmychov@gmail.com,vlad_bochar@ukr.net
}

\title{
ПіАтримка прийняття рішень у проектно-орієнтованому організаційному управлінні засобами VBA
}

Для оперативного реагування інформаційної системи управління проектом, реалізованої в Excel, на зміни початкових даних, необхідно максимально зменшити число основних і допоміжних операцій, які виконуються вручну. Для иъього засобами вбудованої мови програмування VВА реалізовано сервісний програмний модуль, який автоматизує виконання цих операчій, у вигляді багатофункціонального макросу. Для практичного використання розроблено робочу книгу-иаблон із вбудованим макросом, розраховану на керівників проектів без програмістської підготовки. Розмір мережевої моделі «роботи-вузли» з розширеним набором відношень передування не обмежується, передбачено розв'язання задачі планування та розкладу проекту методами критичного шляху (СРM) та імітаційного моделювання (PERT), задачі скорочення тривалості проекту у форматі «час-вартість», побудову часового графіка попиту на ресурс і схеми мережевої моделі.

Ключові слова: управління проектом, мережева модель проекту, розклад (календарний план, schedule) проекту, задача «час-вартість» (time-cost problem), метод CPM/PERT, таблична модель проекту (project spreadsheet model).

\section{Вступ}

Проектно-оріснтоване управління - базова концепція інтеграції процесів 3 управління проектом: концепція, проектування, планування, організація та контроль виконання, аналіз і регулювання, закриття. На кожному етапі вона зводиться до формування, прийняття та супроводження (моніторинг, контролінг) організаційних рішень 3 неперервного виконання моно- чи макропроектів (портфелів, програм) в умовах змін у їхньому життєвому циклі та необхідності оперативного реагування на них.

У макропроекті з певною структурною організацією і технологічно-орієнтованими підсистемами, керівництво проекту (проектний офіс) має всі повноваження для визначення пріоритетів, дій з управління усіма ресурсними складовими, у

(C) О. Г. Аодонов, А. І. Кузьмичов, В. В. Бочаров 
першу чергу, часом, бюджетом й обмеженими ресурсами, зокрема, залученим персоналом [4].

Здійснення цих процесів ускладнюється необхідністю оперативно приймати та здійснювати відповідальні й обгрунтовані рішення на будь-якому часовому проміжку на будь-якому етапі будь-якого процесу при здійсненні будь-якого проекту при виникненні певної непередбаченої ситуації з ії комплексним впливом на операційне оточення [2]. Характерними прикладами ускладнених управлінських процесів $є$ напружена й технологічно інтенсивна діяльність інфраструктурних підприємств типу транспортних і комунікаційних вузлів ${ }^{1}$, де б, здавалося, за рахунок заздалегідь розроблених деталізованих й апробованих часових графіків, розкладів, планів, маршрутів тощо, не повинні би виникати якісь складнощі. Однак це не так, бо нікуди й ніколи не зникнуть конфліктні, нештатні, критичні чи навіть кризові ситуації, це: непередбачені наслідки відхилень від режимів, будь-які випадковості, технічні, технологічні, людські чи організаційні порушення чи збої, часто iз ланцюговою поведінкою. Невипадково виник самостійний напрямок з управління змінами та трендами, де пошук раціональних змін усталених об'єктів, як реакція на нештатні ситуації, є предметом спеціальних досліджень [3].

Тож прогресивна за суттю орієнтація організаційного управління на теоретичні, технологічні та інструментальні засоби проектного менеджменту, де застосовуються ефективні засоби оптимізаційних обчислень у мережевому моделюванні проектів і візуалізації отриманих результатів, невпинно і поступово підсилюється введенням необхідної сервісної програмної підтримки, що направлена на якнайшвидше формування раціональних рішень як обгрунтованої реакції на відхилення від запланованих дій.

\section{Мета і резумьтати досліАжень}

Робота є продовженням [1], де був представлений опис оригінальної технології прийняття та супроводження оперативних рішень побудовою математичних моделей проектної діяльності на платформі електронних таблиць (project spreadsheet model), де наголос зроблено на ефективній алгоритмізації за рахунок застосування апарату математичної оптимізації і вбудованих аналітичних засобів на ії пробній реалізації в Excel. Ясно, що ефективність цієї технології залежить від програмного інструментарію, що застосовується в управлінській практиці. Тож на етапі впроваджень з'ясовано, що у запропонованій технології $є$ ділянки операцій, які, не вимагаючи від користувача програмістської підготовки, здійснюються вручну, це, зокрема, формування додаткових таблиць, виконання креслень для виведення результатів обчислень у наочній формі тощо. Ці операції знижують ефективність цієї технології щодо оперативності формування проектних рішень у разі внесення змін до моделі. Крім того, застосування аналітичних засобів (надбудов Solver Excel чи Premium Solver) є позитивним фактором, якщо розмір задачі не суперечить системним обмеженням надбудови: для реальної задачі нема проблем

\footnotetext{
${ }^{1}$ Щоб зрозуміти проблеми, що виникають при управлінні крупним аеропортом (Атланта), морським портом (Лос-Анджелес), вокзалом (Нью-Йорк) чи Панамським каналом, рекомендуємо переглянути документальний фільм «Системы управления: Кризис под контролем» (Crisis Control, Discovery Channel, www.ex.ua).
} 
при застосуванні комерційної версії надбудови, у випадку ж користування пробною версією Solver Excel обмежується допустимий розмір задачі до 200 робіт, що $\epsilon$ підставою до еквівалентної заміни надбудови формульною моделлю.

Отже, при незмінності загальної організації обчислювального процесу виявлено характерні сервісні задачі, розв'язання яких має покладатися на мовну розробку програмних модулів - макросів, вбудованих у відповідні робочі документи-шаблони, розрахованих, як і раніше, на користувачів-непрограмістів. За їхньою допомогою певна локальна задача розв'язується одним натисканням кнопки, суттєво пришвидшуючи цим відповідний обчислювальний чи інформаційний процес 3 формування оптимального проектного рішення.

Типові задачі управління проектами з їхнім розв'язанням за макрос-підтримкою поставлені на двох рівнях об'єктів табличного моделювання: моно- та макропроектів.

Модель монопроекту за своєю організацією є стандартним блоком з певним набором автоматично виконуваних сервісних функцій, це: формування таблиці зв'язків між роботами-вузлами; обчислення часових характеристик робіт за допомогою формул; креслення мережі та зображення на ній критичного шляху; побудова часового графіка використаних ресурсів; розв'язання задачі скорочення тривалості проекту (задача «час-вартість»). До цього переліку слід віднести актуальну задачу моніторингу процесу здійснення проекту, де заздалегідь розроблений та узгоджений план і розклад порівнюється з уведеними реальними часовими чи іншими показниками, фіксація відхилень від запланованого розкладу та повторні розрахунки дають змогу оперативно зреагувати формуванням нових рішень уведенням скорегованих часових, ресурсних чи вартісних значень початкових даних для критичних чи кризових робіт.

Модель макропроекту має певну структуру (матричну, ієрархічну, мережеву), що складається 3 монопроектів на певних рівнях (шарах) управлінської діяльності. Наприклад, макропроект із мережевою структурою - це укрупнена проектна мережа, де окрема робота є узагальненням певного монопроекту, довжина критичного шляху монопроекту — це тривалість відповідної роботи макропроекту. Універсальний механізм побудови монопроекту застосовується для побудови укрупнених мережевих моделей відповідних складових інтегрованого проекту. Зв'язки між усіма складовими, представленими окремими файлами, формуються за допомогою гіперпосилань. У результаті таблична модель складно організованого проекту є інтегрованою інформаційною системою, де будь-які зміни на будьякому рівні завдяки встановленим інформаційним зв'язкам приводять до автоматичного оновлення усіх результатів із одночасним їхнім виведенням у наочній формі.

Розв'язується розширена версія задачі мережевого планування та управління проектом, де розширення представлене:

— лагом і набором відношень передування робіт (Ф-С, Ф-Ф, С-Ф, С-С),

- вартісними оцінками для задачі «час-вартість»,

- реальною тривалістю робіт для задачі моніторингу проекту,

- параметрами тривалості роботи $(a, m, b)$ для імітаційного моделювання проекту методом PERT;

— ресурсними попитами для робіт. 
Мінімальний набір початкових даних для обчислення розкладу класичного проекту (з відношенням передування Ф-С, усі лаги нульові) методом критичного шляху: код роботи, нормальна тривалість і перелік попередніх робіт.

Макрос-підтримкою автоматизовано формування допоміжних табличних даних (попередні/наступні роботи, початки/кінці дуг-зв'язків між вузлами-роботами), що вимагає серйозних витрат часу і уваги, та розрахунок часових характеристик робіт за формульною моделлю (завдяки якій розмір задачі практично необмежений) методом критичного шляху (СР). Для введених чи змінених початкових даних для виконання цих дій тепер достатньо одного натискання кнопки Формульна модель. При цьому одночасно готуються дані для розв'язання інших задач, вибір задач - натисканням відповідних кнопок, результат їхніх обчислень розміщується на окремих аркушах робочої книги Excel.

Кінцевий продукт - робоча книга-шаблон, тип файлу: Книга Excel c nоддержкой макросов ( $x l s m)$. Розробка користувачем нової робочої книги зводиться до відкриття цієї книги-шаблону, уведення початкових даних, отримання результатів і збереження табличного документа у вигляді файлу вказаного типу.

Треба мати на увазі, що системою безпеки Excel вбудований макрос буде сприйматися як вірус, тому для коректної роботи треба завчасно виконати команду (Excel 2010): Файл $\rightarrow$ Параметры $\rightarrow$ Центр управления безопасностью $\rightarrow$ Параметры центра управления безопасностью $\rightarrow$ Параметры макросов і у вікні Центр управления безопасностью вибрати параметр Отключить все макросы с уведомлением:

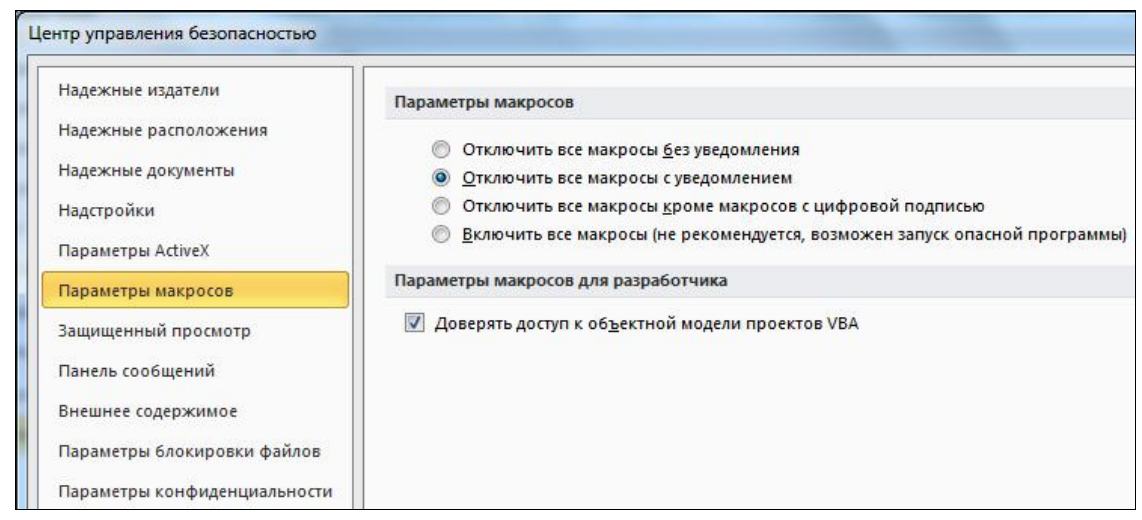

При відкритті книги-шаблону макрос відключено, але з'явиться повідомлення про можливість включення його вмісту:

!) Предупреждение системы безопасности Запуск макросов отключен. Включить содержимое

Увага! При відкритті інших робочих книг не дозволяти запуск макросів невідомого походження.

Для коректної роботи формульної моделі (де діють ітеративні звернення) після відкриття книги-шаблону треба виконати команду: Файл $\rightarrow$ Параметры $\rightarrow$ Формуль $\rightarrow$ Параметры вычислений й вибрати опції: Вычисления в книге $\rightarrow$ автоматически та Включить итеративные вычисления: 


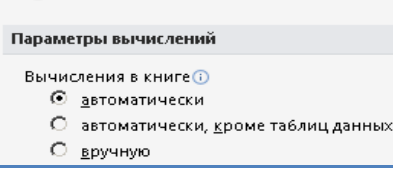

V включить итеративные вычисления Предельное число итераций: $200 \quad 3$ Относительная погрешность: 0,001

\section{Основні задачі побудови мережевої модемі проекту та іії реалізації}

\section{1. Планування та розрахунок розкладу монопроекту}

Проектна мережа складається зі 100 робіт та 191 зв'язку між роботами. Проект розпочинають п'ять $(1 \div 5)$ незалежних робіт. Результат показано на рис. 1,2 (фрагменти).

\begin{tabular}{|c|c|c|c|c|c|c|c|c|c|c|c|c|c|c|c|}
\hline 2 & A & $G$ & $P$ & $R$ & 5 & $T$ & u & v & w & $x$ & $\bar{Y}$ & $z$ & $A E$ & $A F$ & $A G$ \\
\hline 1 & $\begin{array}{l}\text { KoA } \\
\text { pobora }\end{array}$ & \begin{tabular}{|l|} 
Hopмаaлька \\
тривалість \\
\end{tabular} & $\begin{array}{l}\text { nonepeari } \\
\text { pobom }\end{array}$ & $\begin{array}{c}\text { noyatok } \\
\text { Ayre }\end{array}$ & $\begin{array}{l}\text { Kinęo } \\
\text { Ayrm }\end{array}$ & תar & $\begin{array}{c}\text { Bдношеник } \\
\text { передувамия }\end{array}$ & PC & $P \phi$ & $\mathrm{nc}$ & no & $3 P$ & $\mathrm{KW}=$ & 247 & \\
\hline 2 & 1 & 2 & & 1 & 6 & 0 & $a c$ & 0 & $2, \infty$ & 16 & $18, \infty$ & 16,000 & & & \\
\hline 3 & 2 & 3 & & 2 & 6 & 0 & $a-c$ & 0 & 3,00 & 13 & 16,00 & 13,000 & & & \\
\hline 4 & 3 & 3 & & 2 & 7 & 0 & $\theta-c$ & 0 & 3,00 & 13 & $16, \infty 0$ & 13,000 & & & \\
\hline 5 & 4 & 5 & & 2 & 11 & 0 & $a c$ & 0 & $5, \infty$ & 0 & 6,00 & 0 & \multirow{4}{*}{\multicolumn{3}{|c|}{ Формульна модель }} \\
\hline 6 & 5 & 5 & & 3 & 7 & 0 & $a c$ & 0 & 5,00 & 1 & 5,00 & 1,000 & & & \\
\hline 7 & 6 & 4 & 12 & 3 & $\mathrm{~B}$ & 0 & $a x$ & 3 & $7, \infty$ & 18 & $22, \infty 0$ & 15,000 & & & \\
\hline 8 & 7 & 6 & 23 & 4 & 8 & 0 & $a c$ & 3 & $9, \infty$ & 16 & 22,00 & 13,000 & & & \\
\hline 9 & 8 & 5 & 34 & 4 & 9 & 0 & $a x$ & 5 & $11, \infty$ & 17 & 22,00 & 11,000 & & & \\
\hline 10 & 9 & 3 & 4 & 4 & 10 & 0 & $\Phi$ & 6 & $9, \infty$ & 7 & $10, \infty$ & 1,000 & & & \\
\hline 11 & 10 & 4 & 45 & 5 & 10 & 0 & $a x$ & 6 & $10, \infty$ & 6 & $10, \infty 0$ & 0 & & & \\
\hline 12 & 11 & 2 & 267 & 6 & 11 & 0 & $\Phi-c$ & 9 & $11, \infty$ & 22 & 24,00 & 13,000 & & & \\
\hline 13 & 12 & 2 & 7 & 7 & 11 & 0 & $a-c$ & 9 & $11, \infty$ & 22 & 24,00 & 13,000 & & & \\
\hline 14 & 13 & 2 & 789 & 7 & 12 & 0 & $a-c$ & 11 & $13, \infty$ & 22 & 24,00 & 11,000 & & & \\
\hline 15 & 14 & 7 & 9 & 7 & 13 & 0 & $a c$ & 9 & $16, \infty$ & 10 & $17, \infty$ & 1,000 & & & \\
\hline 16 & 15 & 7 & 910 & 8 & 13 & 0 & $a-c$ & 10 & $17, \infty$ & 10 & 17,00 & 0 & & & \\
\hline
\end{tabular}

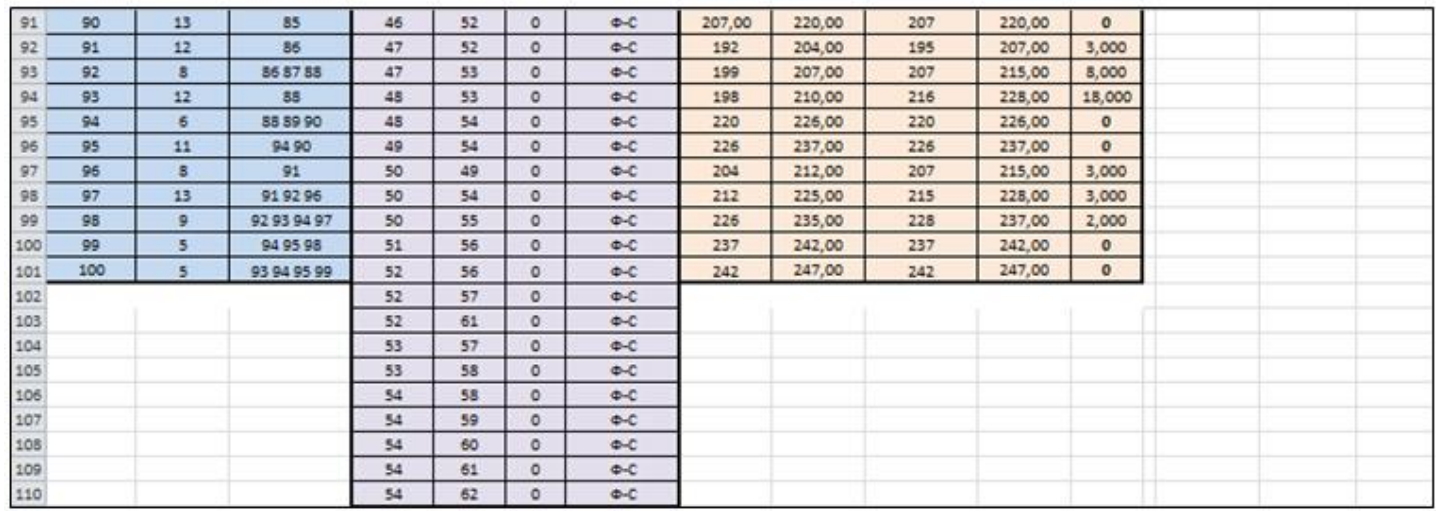

Рис. 1. Часові характеристики проекту

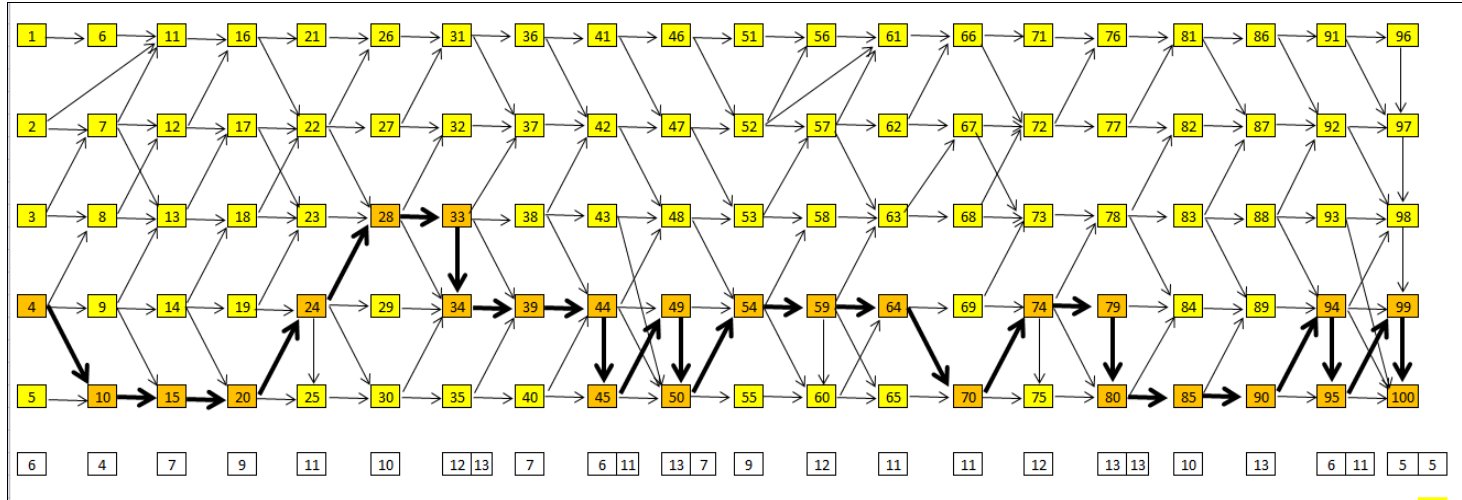

Рис. 2. Мережева модель проекту (позначено критичний шлях) 


\section{2. Побудова часового графіка попиту ресурсу}

Для заданого часового діапазону (початок періоду від 0 до довжини критичного шляху) на екран монітора (вміщує 60 періодів) виводиться діаграма Гантта 3 урахуванням ресурсного попиту для виконання кожної роботи, за яким будується часовий графік попиту на ресурс (один чи декілька). Результат відображено на рис. 3 (періоди: 158-217, фрагмент).

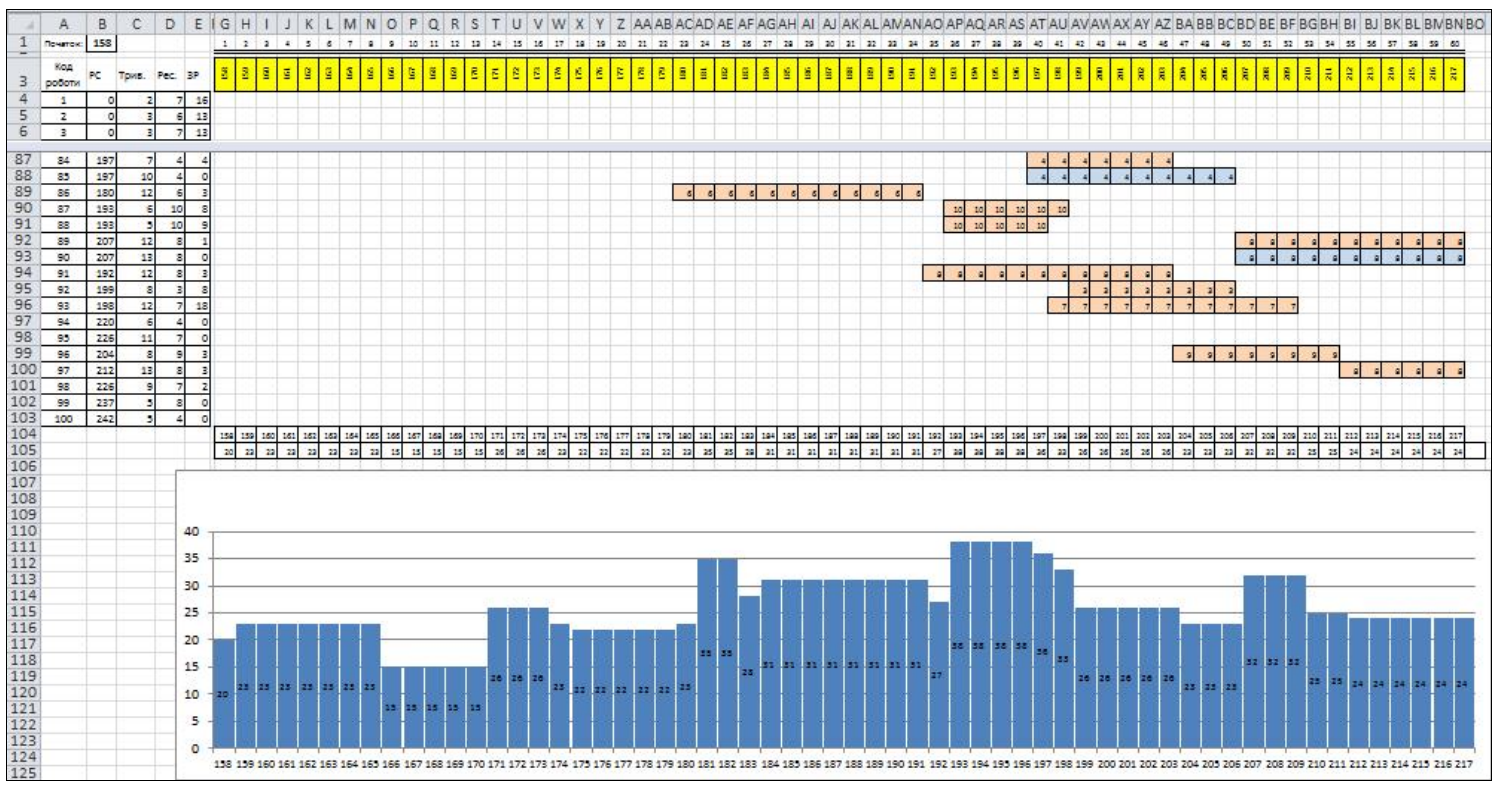

Рис. 3. Діаграма Гантта, ресурсний графік

\section{3. Моніторинг процесу реалізації проекту}

Відомо, що найбільш розповсюдженою проблематикою, що стала навіть вмістом проектного менеджменту, є загальне та календарне планування (розробка розкладу) проектної діяльності. Цей наголос пояснюється суттю та складністю прикладних задач, а також привабливою для дослідників математичною «красою» оптимізаційних задач, до розв'язання яких зводиться технологія мережевого моделювання проектів і на платформі якого визначаються базові управлінські рішення.

Однак етап реалізації спланованого та детально розробленого проекту супроводжується виникненням не менш складних задач, ніж розрахунок розкладу 3 урахуванням часових, вартісних і ресурсних обмежень. Оскільки проект здійнюється в реальних умовах, певні ускладнення навряд чи можливо було б очікувати та врахувати в лабораторних умовах на етапі планування. Саме тут виникають зміни, які необхідно в оперативному режимі внести до предметної області, щоби зберегти живучість проектної моделі, маючи змогу оперативно оцінити наслідки цих змін і прийняти скореговане рішення щодо подальших дій.

Наприклад, у певний момент часу в процесі здійснення проекту «наживо» з'ясовано, що тривалість однієї чи групи зв'язаних між собою робіт змінилася, зменшилася, чи частіше, збільшилась, що викликало фактичне відхилення від розкладу, тобто, від значень планових часових характеристик. Можливі наслідки цих 
змін: довжина критичного шляху збільшилась, змінена конфігурація критичного шляху (певні критичні роботи стали некритичними, а певні некритичні роботи стали критичними), змінені часові характеристики окремих некритичних робіт, хоча $\epsilon$ роботи поки що із незмінними властивостями. Виникає ситуація «ПланФакт», де треба миттєво провести аналіз поточного стану предметної області, побудувати прогноз виконання проекту, виявити проблеми («вузькі місця») й знайти шляхи для їхнього розв'язання. Робоча книга-шаблон виконує ці дії у наочній (графічній) формі (рис. 4), якщо дозволяє розмір екрану, чи у вигляді таблиці.

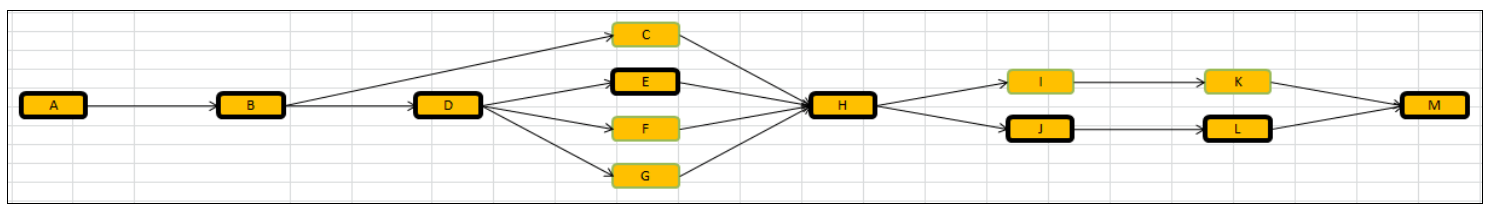

a)

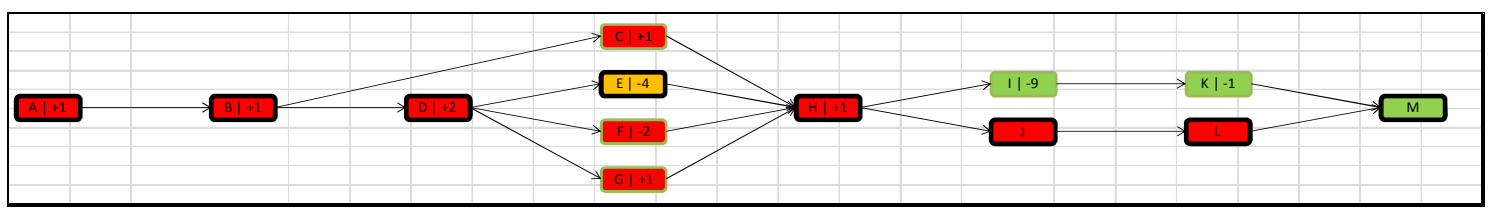

б)

Рис. 4. Графічна ілюстрація ситуації «план-факт» (формується макросом):

a) план - критичний шлях: $\mathrm{A} \rightarrow \mathrm{B} \rightarrow \mathrm{D} \rightarrow \mathrm{E} \rightarrow \mathrm{H} \rightarrow \mathrm{J} \rightarrow \mathrm{L} \rightarrow \mathrm{M}$;

б) факт - критичний шлях: $\mathrm{A}(+1) \rightarrow \mathrm{B}(+1) \rightarrow \mathrm{D}(+2) \rightarrow \mathrm{E}(-4) \rightarrow \mathrm{H}(+1) \rightarrow \mathrm{J} \rightarrow \mathrm{L} \rightarrow \mathrm{M}$.

Некритичні роботи зі змінами: $\mathrm{F}(-2), \mathrm{G}(+1), \mathrm{I}(-9), \mathrm{K}(-1)$

Таблична форма реалізована макросом у вигляді трьох аркушів робочої книги-шаблону: План, Факт (роботи, що затримуються чи випереджають план), Порівняльний звіт (критерій порівняння - ранній фініш робіт). Якщо, наприклад, змінено планові тривалості двох робіт: $5(5 \rightarrow 8)$ та $96(8 \rightarrow 3)$, (рис. 5, $a$, фрагмент), автоматично буде отримано результат, розміщений на аркушах Факт та Порівняльний звіт (рис. 5,б, фрагмент).

\begin{tabular}{|c|c|c|c|c|c|}
\hline \multicolumn{6}{|c|}{ Критичний шлях (План) } \\
\hline Вузли & 4 & 10 & 15 & 20 & 24 \\
\hline & 95 & 99 & 10 & & \\
\hline
\end{tabular}

a)

\begin{tabular}{|c|c|c|c|c|c|c|c|c|}
\hline \multicolumn{9}{|c|}{ Критичний илях (Факт) } \\
\hline Вузли & 5 & 10 & 15 & 20 & 24 & & & \\
\hline & & & & & & & & \\
\hline \multicolumn{9}{|c|}{ Ранній фініш (Факт) } \\
\hline Затримуються & 5 & 10 & 15 & 20 & 24 & 98 & 99 & 100 \\
\hline Випереджають & 96 & 97 & & & & & & \\
\hline
\end{tabular}

б)

Рис. 5. Порівняльний аналіз План-Факт: а) планові значення показників

б) фактичні значення показників 
Світова практика [4] свідчить, що перегляд плану проводиться, як правило, щотижня, тож розроблена робоча книга-шаблон із вбудованим макросом дає можливість оперативно отримувати оновлені дані з будь-якою частотою (рис. 6-8).

\section{Макрос: панель кнопок-інструментів та опис}

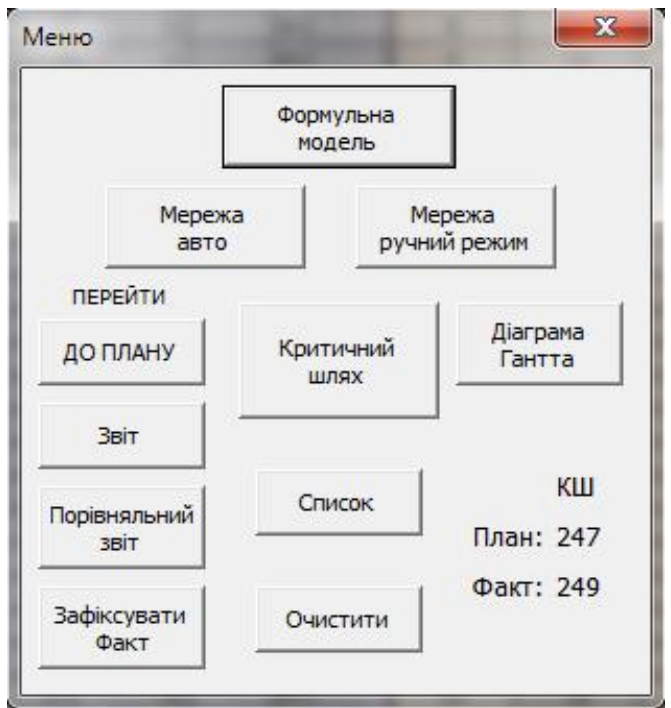

Панель кнопок незакріплена, іiі можна переміщувати у зручне місце робочого аркушу. Виводиться оновлена тривалість проекту (КШ) порівнянням планового та фактичного значень.

\section{ФУНКЦІї КНОПОК МАКРОСУ}

Формульна модель - заповнює основну таблицю на аркуші Дані необхідними для роботи моделі даними і формулами та здійснює за ними усі розрахунки.

Мережа авто - автоматично креслить увесь мережевий графік проекту на окремому аркуші.

Мережа ручний режим - креслить мережевий графік покроково (по одній роботі з їі наступними зв’ язками)

Критичний шлях - позначає на мережі: критичні роботи, ті, що затримуються, випереджають чи зі зміненими довжинами.

Список - виводить список критичних робіт.

Діаграма Гантта — креслить на окремому аркуші діаграму Гантта.

ДО ПЛАНУ (ДО ФАКТУ) - зміна режиму роботи

Звіт - для поточного Факту формує аркуш зі списками критичних робіт з їхнім часовими характеристиками у порівнянні з Планом.

Порівняльний звіт - формує аркуш 3 результатами порівняння поточного і зафіксованого планів

Зафіксувати Факт - зберігає результати порівняння поточного Факту з Планом

Очистити - видаляє, якщо $\epsilon$, мережевий графік, список критичних робіт й усі звіти.

Рис. 6. Вікно макросу

\begin{tabular}{|c|c|c|c|c|c|c|c|c|c|c|c|c|c|c|c|c|c|c|c|}
\hline 4 & A & B & D & $\mathrm{E}$ & $\mathrm{F}$ & G & $\mathrm{H}$ & I & J & K & L & M & $\mathrm{N}$ & 0 & $\mathrm{P}$ & Q & $\mathbf{R}$ & $\mathrm{s}$ & $\mathrm{T}$ \\
\hline 1 & Змін & Кш & Критичні роботи & \multicolumn{16}{|c|}{ Роботи } \\
\hline 2 & План & Факт & 3'явилися на КШ & 2 & 3 & 7 & 11 & 16 & 22 & 58 & 63 & 67 & 73 & 78 & 83 & 87 & 92 & 97 & 98 \\
\hline 3 & 249 & 252 & Зникли з КШ & 5 & 10 & 15 & 20 & 24 & 59 & 64 & 70 & 74 & 79 & 80 & 85 & 90 & 94 & 95 & \\
\hline 4 & & & Роботи зі зміненими РФ & \multicolumn{13}{|c|}{ Роботи } & & & \\
\hline 5 & & & Затримуються & 11 & 16 & 21 & 22 & 26 & 27 & 31 & 36 & 41 & 46 & 51 & 96 & 97 & & & \\
\hline 6 & & & Випереджають & 74 & 75 & 79 & 80 & 85 & 90 & & & & & & & & & & \\
\hline 7 & & & Вже не затримуються & 74 & 75 & 79 & 80 & 85 & 90 & & & & & & & & & & \\
\hline 8 & & & Вже не випереджають & 96 & 97 & & & & & & & & & & & & & & \\
\hline
\end{tabular}

Рис. 7. Зведена інформація для прийняття рішень 


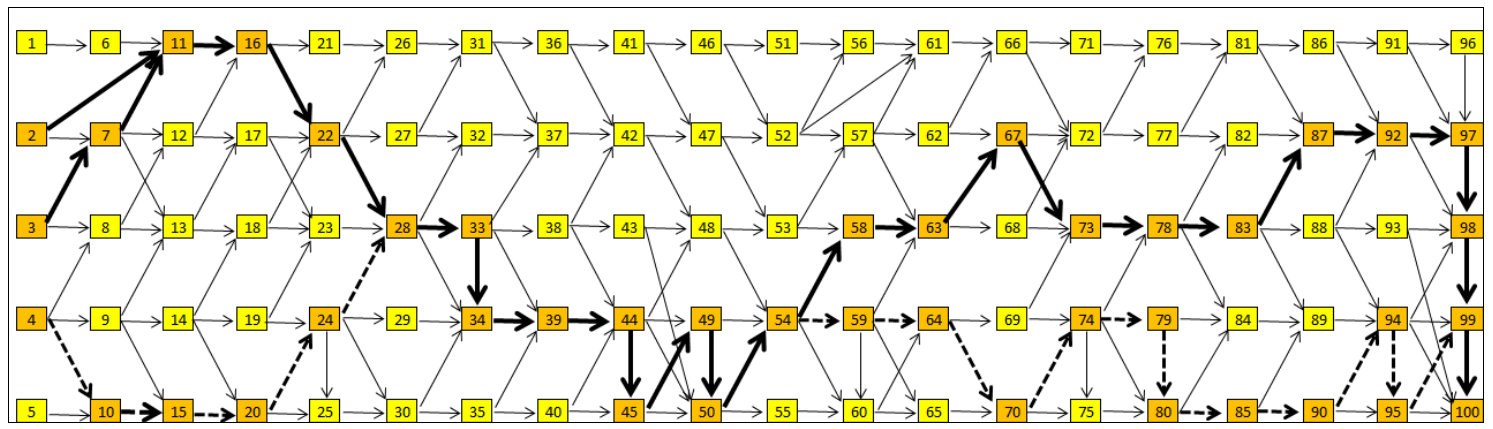

Рис. 8. Рішення прийнято: оновлений мережевий графік

\section{Висновки}

Запропонований матеріал розрахований на рядових проект-менеджерів без програмістської підготовки зі сфери малого та середнього бізнесу, які без залучення професійних консультантів і придбання спеціалізованих програмних продуктів можуть ефективно використовувати сучасний апарат проектного менеджменту у звичному робочому середовищі електронних таблиць MS Excel. Формульна реалізація математичної моделі про пошук критичного шляху з урахуванням ресурсних обмежень вивільняє користувача від вимушеного звернення до застосування надбудови-оптимізатора, чим знімає проблему обмеженого розміру задачі оптимізації. Розроблений програмний продукт із макрос-підтримкою $є$ готовим для користування робочим інструментом, де певні процедури здійснюються автоматично.

1. Додонов А.Г. Оперативное принятие решений в нештатных ситуациях: модель расписания проекта по критерию «время-стоимость» / А. Г. Додонов, А. И. Кузьмичев // Реєстрація, зберігання і оброб. даних. - 2014. - Т. 16, № 2. - С. 122-132.

2. Thamhain H. Managing Technology-based Projects: Tools, Techniques, People and Business Processes / H. Thamhain. - Wiley, 2014. - 527 p.

3. Lewis J. Project Planning, Scheduling \& Control: The Ultimate Hand-on Guide to Bringing Projects in on time and on budget / J. Lewis. - [5-th ed.]. - McGraw Hill, 2011. — 593 p.

4. Nicholas J. Project Management for Business, Engineering, and Technology. Principles and Practice / J. Nicholas, H. Steyn. — [3-rd ed.]. — Elsevier, 2008. — 707 p.

5. Математические основы управления проектами: учеб. пособ. / С.А. Баркалов [и др.]; под ред. В.Н. Буркова. - М.: Высш. шк., 2005. - 423 с. 